\title{
Könyvszemle
}

SIPOS JÚLIA GONDOZÁSÁBAN

\section{POPULAR MUSIC, TECHNOLOGY, AND THE CHANGING MEDIA ECOSYSTEM. FROM CASETTES TO STREAM}

Barna Emília és Tófalvy Tamás szerkesztésében 2020-ban jelent meg a könnyüzene, technológia és a média gazdaságtanával foglalkozó angol nyelvü kötet. A kiadó (eddig) huszonnégy kötetes sorozatban foglalkozik a könnyüzene, a kultúra és az identitás témakörével, a szerkesztőpáros kötete ennek a sorozatnak a friss, negyedszázadik eleme.

A szerkesztői bevezetést (mely Tófalvy Tamás felvezető, szintetizáló tanulmánya) négy tematikus blokk követi, összesen tizennégy önálló tanulmánnyal, jellemzően nemzetközi szerzők tollából, a két szerkesztő egy-egy tanulmánnyal képviselteti magát. A szerzőket a kötet elején egybekezdéses bemutatással ismerhetjük meg. A bevezetésben a tágabb gondolati környezetet (változó szereplök, változó technológiák, üzleti modellek és a zene különböző megjelenési formái) vázolja fel Tófalvy Tamás, és amellett, hogy kiemeli a technológiai megoldások determinisztikus hatását, hangsúlyozza, hogy nem ezek a döntők, hanem a társadalmi minták és a használat ad új értelmet az állandóan változó funkcióknak, egy folyamatosan változó, és követendő területet jelentve ezzel.

Az első tematikus egység a technológiai hálózatokkal és a könnyüzene viszonyával foglalkozik. Paolo Nagaudda az első tanulmányban a zenei színterekkel mint infrastrukturális környezetekkel foglalkozik, azokkal a kihívásokkal, amelyeket a digitális média terjedése hozott, a közösségi média zenei színtérré válásától kezdve az online streaming platformok technológiai, stílus- és véleményformáló erejéig. Három dimenzióban tanulmányozza a kérdést, a digitális platformok, az adatok szervezése és menedzsmentje, illetve az új zenei formátumok fejlődésének oldaláról. Stéphane Costantini a zenei színtereket és a zeneközpontú hálózatokat vizsgálja a digitalizáció szemüvegén keresztül. A digitalizációt a közösségi média terjedésének hatásain és a digitális terjesztői hálózatokon keresztül is elemzi, figyelembe véve a zenei brand mint üzleti termék terjedését és sikerét. Fontos eredménye, hogy bár a terjesztői hálózatok és technikák globálisak, nagyon sok múlik a zenekar földrajzi, kulturális meghatározottságán azon a téren, hogy melyik megoldást használják sikeresen. Ugyanilyen fontos, 
hogy a zenészeknek ebben a környezetben már mint szolgáltatóknak, ügyfélmenedzsereknek kell müködniük, nem elég „puszta” tartalomszolgáltatóknak lenniük. Tófalvy Tamás az underground fogalma felöl közelít ehhez a kérdéshez. Több féle underground létezik (politikai, nem hivatalos, nem mainstream, illetve a kifejezetten rétegzenék. A (digitális) média az underground fogalmát és környezetét is megváltoztatta az elmúlt négy évtizedben. Önreflektáló és réteg jellege megmaradt, de célja, a téma, amihez képest definiálja magát, és eszközei is megváltoztak.

A második nagy tematikus egység hívószavai az ízlés, a hitelesség és a digitális média. Barna Emília a Song Exploder esettanulmánya segítségével (és sok más forrást igénybe véve) a zenei fogyasztók ízlésváltozásait vizsgálja, kiemelve a mit fogyaszt mellett a hogyan és milyen célból fogyaszt jelenségek formáló hatását. A digitális és online zenei környezet kiváló terep a zenei mindenevőknek, a zenei divatkövetőknek, a vegyes zenei ízléssel rendelkezőknek, akik (elvileg) könnyedén alakíthatják ki személyre szabott környezeteiket céljaiknak megfelelöen. Rónai András tanulmányában a fogyasztók kényelmi igényeiről értekezik. Egy adott platformon belül a zenei listák vagy újabban a hangirányítás alapú zenehallgatás a keresés és az fogyasztott zene ismeretének kényelmét adják meg a fogyasztóknak. Ez az érintkezésmentes zenehallgatás visszaviszi a fogyasztókat a zenehallgatás alapvető élményéhez, amikor kényelmes módon, csak a zenehallgatás igényének kell jelentkeznie, és az a lehető legegyszerübb módon megvalósul. A következő tanulmányt három szerző jegyzi (Samira van Bohemen, Julian Schaap és Pauwke Berkers), elemzésükben a nemek megkülönböztetésén alapuló zenei ízlésformálással foglalkoznak regionális és etnikus kontextusban. Bár a kulturális és etnikai háttér még mindig meghatározó a zenei választásokban és választékban, az önreflexió és hangulat egyre növekvő szerepe a zeneválasztásban enyhíti ezt. Jessica Edlom a hitelesség és a brandépítés viszonyát vizsgálja, elemzése nemcsak a zeneipar, de általában az egész influencer világra érvényes. Egyszerre kell hitelesnek és egyéninek tünni úgy, hogy közben erős brandet is szeretnének kiépíteni ennek populáris követelményeivel. Természetszerüleg azok a sikeresek, akik az egyensúlyt hosszú távon meg tudják őrizni.

A harmadik nagyobb egység a zenefogyasztás fizikai megjelenési formáival foglalkozik. Zhongwei Li az 1990-es évek Kínájának tárgyi zenei kultúrájával foglalkozik. A korszak akkor jellemző, a nyugati piacról elszármazó, leselejtezett, vágással jelölt zenehordozói világa mára már eltünt. Az érdekes esettanulmány és korkép részletes elemzéssel mutatja be a megfogható zene kulturális hatásait. Benjamin Düster hasonló elemzést végez a huszonegyedik század eleji Japán területén a magnókazetta formátumának jelentőségével kapcsolatosan. Ez a kultúra egyáltalán nem tünt el, sőt, jelentősége, vonzereje megmaradt, bár a kazettakiadók száma csökken. A japán független zenei világ „,cool” adathordozója maradt. A szerző ennek a megmaradásnak a kulturális hátterét boncolgatja. 
Az utolsó tömb a közösségi médiára fókuszál. Andrew Whelan írása a zenéről szóló diskurzusok világába viszi el olvasóját. A Vaporwave bemutatkozó oldal esettanulmányát kibontva (és a gőzfelhő terjedésének analógiáját szélesebb körre kiterjesztve) egészen a kapitalizmus kritikájáig jut el. Fontos megállapítása, hogy a zene müfaja is formálja magát az adott zenéről szóló írást esztétikai és szemiotikai elemeiben is. Loic Riom a Sofar Sounds esettanulmányán keresztül a meglepetés, felismerés, kedvenccé válás folyamatát vizsgálja. A Sofar Sounds havonta négyszáz olyan zenei eseményt szervez, ahol a hallgatók nem ismerik elöre az előadó nevét, elvileg a zene élménye a meghatározó fogyasztási élmény, és nem az ismertsége. Kibontja ennek a „vak” találkozásnak a szociológiáját, a másodlagos információk befolyásoló erejét, és a felfedezés élményét. Cibrán Tenreiro Uzal a spanyol zenei színtéren vizsgálja az amatôr koncertvideók terjedését és jelentőségüket az underground rétegben. Ezek a videók mind az ismertség növelésére, készítőik hírnevének növekedésére, a hivatalos médiával való szembenállásra, illetve a kulturális réteg saját identitásának növelésére is alkalmasak, terjedési platformjuk a digitális média. James Williams a zenei szubkultúra és a politikai témájú stand-up comedy határvonalát veszi górcső alá, különös tekintettel a mindkét területen mozgó szereplökre.

A kötet egymásra nem reflektáló, nem egymásra építkező, de értékes és fontos tanulmányok gyüjteménye, tág kitekintésekkel és színes esettanulmányokkal. Mind a zene világa szereplőinek, a digitális tartalomipar üzletembereinek, mind pedig a digitális média kutatóinak hasznos forrásgyüjteménye és segédanyaga.

(Tamas Tofalvy - Emilia Barna editors: Popular Music, Technology, and the Changing Media Ecosystem. From Casettes to Stream. Palgrave Macmillan, 2020, 267 o.)

Rab Árpád

PhD, egyetemi docens, Budapesti Corvinus Egyetem 